\title{
SACRED SCIENCE vs. SECULAR SCIENCE: Carut Marut Hubungan Agama dan Sains
}

\author{
Samsul Hidayat \\ STAIN Pontianak \\ hidayat_ss@yahoo.co.id
}

\begin{abstract}
Abstrak
Tulisan ini berupaya mengetahui pergumulan yang terjadi antara Agama dan Sains. Hipotesis yang diajukan adalah: Hubungan antara Agama dan Sains mengalami ketegangan dan variasi didalamnya. Ketegangan yang terjadi antara Sains dan Agama disebabkan karena perbedaan perspektif yang digunakan untuk memahami realitas sebagai sumber pengetahuan manusia. Kalau sains mendekati persoalan eksistensi melalui observasi dan eksperimen, sedangkan agama membangun landasan epistemologinya berdasarkan wahyu. Pada abad 19 dan sebagian besar abad 20, gagasan yang dominan adalah sains dianggap mampu memecahkan seluruh persoalan manusia, namun faktanya sains juga telah melahirkan senjatasenjata pemusnah massal dan polusi lingkungan, termasuk merusak keseimbangan aspek spiritual dan material dalam kehidupan manusia. Belakangan muncul para ilmuwan teolog dari beberapa agama yang berupaya mencari jalan tengah untuk menyelesaikan problematika kemanusiaan dan alam dengan menjembatani carut marut hubungan sains dan agama yang tampaknya belum berakhir.
\end{abstract}

\section{Abstract}

SACRED SCIENCE VS. SECULAR SCIENCE: CHAOS OF RELIGION AND SCIENCE RELATIONSHIP. This paper seeks to know the struggle that occurs between Religion and Science. The hypothesis forwarded is: the relationship between religion and science experiences tensions and variations. The tensions between science and religion are mostly due to the different perspectives used to understand the reality as a source of human knowledge. While the science approaches the problem of the existence through observation and experimentation, religion, on the other side, bases 
its epistemological foundation on revelation. From the 19th to the 20th century, the idea that science is capable of resolving the whole problem of man was really dominant, leaving aside the fact that science has given birth to mass-destructive weapons and environmental pollution and has undermined the balance between the spiritual and material aspects of human life. Later, a number of theologians and religious scientists emerge, seeking the ways to solve the problems of humanity and nature and trying to bridge the tangled relationship between science and religion.

Key words: sains sakral; sains sekular; teistik; ateistik; kreasionisme.

\section{A. Pendahuluan}

Kalau kita mencermati buku mata kuliah Ilmu Alamiah Dasar yang dirancang Dirjen Pendidikan Tinggi Depdiknas tahun 2003, di dalamnya akan ditemukan materi yang memuat tentang agama dan sains. Karakteristik yang paling menonjol dari materi tersebut adalah wacana agama dan sains diajarkan secara dogmatis dan normatif. Pandangan-pandangan yang dimuat cenderung gampangan dan Buchaillistik, di mana teks-teks agama dicocok-cocokkan agar sesuai dengan temuan baru dalam sains. Agama dan sains dalam hal ini tidak memiliki ketegangan satu sama lain, karena dianggap bisa saling mengisi dalam menjelaskan dan memahami realitas. Hal ini tampak naif dan salah kaprah jika dihubungkan dengan ketegangan yang tak kunjung henti antara agama dan sains bahkan sejak abad ke-17, di mana ilmuwan Galileo Galilei yang mendukung teori bumi mengitari matahari ditentang Paus Gereja Vatikan yang memahami kosmos berdasarkan penafsiran literal kitab suci. Artinya persoalan ketegangan antara sains dan agama tidak cukup memadai jika hanya menggunakan pendekatan teologis - normatif semata. Diperlukan pendekatan-pendekatan baru dalam mempertemukan agama dan sains sebagai wilayah yang saling mengisi pengetahuan manusia tentang realitas.

Pada masa abad 19 dan sebagian besar abad 20, gagasan yang dominan adalah bahwa sains per se bisa memecahkan semua masalah dan mendatangkan kebahagiaan dan kesejahteraan bagi umat manusia. Tidak diragukan lagi bahwa sains dan hasil teknologisnya telah membawa banyak berkah bagi manusia, tapi utopia yang dijanjikannya tidak pernah terejawantahkan. Sebaliknya, sains telah 
melahirkan senjata-senjata pemusnah massal dan polusi lingkungan, dan merusak keseimbangan aspek spiritual dan material dalam kehidupan manusia. Umat manusia menyaksikan sejumlah perang di berbagai belahan dunia, kemiskinan, kelaliman, kekedapan moral dan kekerasan. Kini dunia yang telah maju, dengan segala keunggulan teknologinya, mencari-cari makna sesuatu yang tidak disediakan oleh kemajuan sains dan teknologi bagi manusia.

Paper ini bertujuan memaparkan posisi agama dan sains, sebagai sarana memahami realitas sebagai sumber pengetahuan manusia. Uraian juga diarahkan pada upaya menjembatani "ketegangan" antara agama dan sains yang masih terjadi sampai sekarang, terutama antara kalangan teistik dan ateistik, atau antara sains kuno dan sains baru.

\section{B. Tipologi Hubungan Agama dan Sains}

Sulit untuk membantah jika selama ini hubungan antara agama dan sains ternyata bukan 'baik-baik saja', tapi banyak ketegangan dan variasi didalamnya. Posisi diametral itu terjadi mulamula karena ilmuan dan agamawan mendekati pertanyaan perihal eksistensi dari titik berangkat yang sama sekali berbeda. Sains mendekatinya dari observasi dan eksperimen, sedangkan agama dibangun berdasarkan wahyu yang turun dari langit. Pertentangan itu kian keras ketika ilmuwan menganggap diri rasional dan memandang kaum agamawan sebagai wakil dari sikap dan pandangan yang tidak rasional. Namun belakangan tumbuh sikap di kalangan ilmuwan dan agamawan untuk mencari "jalan berdialog" antara dua dunia yang terasa terpisah itu.

Peletak dasar wacana sains dan agama yang juga doktor dalam bidang fisika dan teologi, Ian G. Barbour (2000) dalam bukunya When Science Meets Religion: Enemies, Strangers or Partners membagi empat tipologi hubungan agama dan sains; Pertama, pendekatan konflik yang memandang agama sebagai musuh abadi sains. Tokohtokoh pendekatan materialisme ilmiah ini seperti Richard Dawkins, Peter Atkins, dan Carl Sagan. Kedua, pendekatan independensi yang menganggap tidak tepatnya suatu penghakiman (judgement) baik terhadap agama maupun sains. Perbedaan ini bisa saja disebabkan karena perbedaan metodologi yang digunakan oleh masing-masing 
wilayah, di samping ada pertimbangan pragmatis yang berupaya memisahkan keduanya demi menghindari konflik yang tak berujung. Pendekatan yang ketiga adalah dialog, yaitu pendekatan yang berupaya melihat adanya kesamaan dan perbedaan diantara sains dan agama. Bagi Barbour, pendekatan ini lebih konstruktif ketimbang pendekatan independensi karena bagaimanapun, sains dan agama merupakan sarana memahami realitas sebagai sumber pengetahuan manusia. Keempat, pendekatan integrasi, yaitu pendekatan yang menurut Barbour lebih menjanjikan dalam menyelesaikan sejumlah persoalan hubungan agama dan sains. Pendekatan ini merupakan tuntutan alamiah dari pendekatan dialog yang membutuhkan penjelasan lebih sistematis interaksi yang konstruktif dan integratif antara sains dan agama.

Sampai saat ini, wacana tentang hubungan sains dan agama terus mencari bentuk interaksinya yang tepat. Banyak tawaran yang menarik disodorkan. Tapi, jika tidak waspada, bisa-bisa wacana ini terjebak dalam pembenaran ala (Maurice) Buchaillisme - yang cenderung mencari pembenaran atas teori ilmiah, contohnya Teori Dentuman Besar, dengan menyebutkan bahwa itu ada dalam kitab suci al-Qur'an. Inilah yang coba dihindari, antara lain oleh Bruno Guiderdoni, Direktur Riset Institut Astrofisika Paris. Dengan memiliki kesamaan epistemologi, yaitu sebagai proses pencarian kebenaran yang terbuka, sains dan agama seharusnya tidak mengalami konflik yang berkepanjangan. Sebagaimana pendapat yang umum dipahami, sains berkaitan dengan "fakta", sementara agama berkaitan dengan "makna", atau sains berupaya menjawab "bagaimana" dan agama "mengapa", artinya sains dan agama telah memiliki ranah dan wilayah yang berbeda tapi saling mengisi. Namun menurut Bruno Guiderdoni, ${ }^{1}$ persoalannya adalah memang benar bahwa sains berkaitan dengan sebab-sebab efisien dan agama dengan sebab-sebab final, tapi arus umum dalam perkembangan sains adalah bahwa sebab-sebab efisien sering menyisihkan sebab-sebab final dan akhirnya melenyapkannya.

${ }^{1}$ Bruno Guiderdoni, "Did The Universe Begin?: Cosmology and Metaphysics for the XXIst Century", dalam International Conference on Religion and Science, (Yogyakarta: Comparative Religious Studies Gadjah Mada University and Templeton Foundation, USA, 2003), h. 1-2. 


\section{Sains Sakral vs. Sains Sekular}

Dari dunia Islam untuk beberapa lama sempat menguat gagasan islamisasi sains ataupun sains Islam, dengan pemukanya seperti Seyyed Hossein Nasr - yang mengkritik keras modernisme sebagai akibat perkembangan sains modern - dan Ziauddin Sardar. Namun gagasan mereka banyak dikritik bahkan dari kalangan muslim sendiri karena ide mereka dianggap tidak realitistik karena harus membongkar sistem sains yang sudah ada dan menggantinya dengan sistem yang sama sekali baru. Selain akan bermakna sains Islam akan menjadi eksklusif dan kehilangan spirit universalitasnya. Alih-alih merumuskan suatu sistem sains yang baru, fisikawan seperti Abdus Salam (Peraih Nobel Fisika 1979) justru lebih menganjurkan agar kaum muslim berikhtiar mengejar ketertinggalan mereka dalam bidang sains dari sejawatnya di Barat. Berbeda dengan Abdus Salam, ilmuwan keturunan Iran, Mehdi Golshani, dalam makalahnya pada International Conference on Religion and Science di Yogyakarta yang berjudul Science and The Sacred: Sacred Science vs. Secular Science, berusaha menguraikan sejumlah pokok masalah menyangkut sains sakral dan sains sekular. Walaupun konsep 'sains sakral' dan 'sains sekular' tampak membingungkan bagi sebagian orang, Golshani mengartikannya sebagai berikut:

"Sacred science is one that is framed within a theistic worldview-one that considers God as the Creator and Sustainer of the universe, does not confine the existence to the material realm, believes in a telos for the created world and admits a moral order. Secular science, on the other hand, is indifferent with respect to all these points".

(sains sakral adalah sains yang terbingkai dalam pandangan dunia yang teistik - pandangan dunia yang menganggap Tuhan sebagai Pencipta dan Pemelihara alam semesta, yang tidak mengurung wujud dalam wilayah material, meyakini pada tujuan bagi alam penciptaan dan mengakui aturan moral. Sains sekular, pada sisi lain, bersifat abai terhadap segenap poin tersebut). ${ }^{2}$

${ }^{2}$ Mehdi Golshani, "Science and The Sacred: Sacred Science vs. Secular Science", dalam International Conference on Religion and Science, (Yogyakarta: Comparative Religious Studies Gadjah Mada University and Templeton Foundation: USA, 2003), h. 19. 
Beberapa perbedaan pandangan antara sains sakral dan sains sekular dapat terlihat seperti; a) cara pandang terhadap alam fisik sebagai satu-satunya yang ada atau sesuatu yang diciptakan; b) spesialisasi yang berbuntut pada fragmentasi sains atau mencari kesatuan yang mendasari tatanan penciptaan; c) mengabaikan/ menolak ide adanya tujuan (teleologi) bagi alam atau menerimanya; d) mengembangkan kenetralan pada nilai atau mengintegrasikan pengetahuan dengan serangkaian nilai; e) sains digunakan untuk mengendalikan dan memanipulasi alam dan masyarakat atau dipakai untuk mendapatkan kebijaksanaan dan memecahkan masalah-masalah individu/ masayarakat; f) bungkam terhadap makna dan tujuan kehidupan manusia dan tentang moralitas atau tidak mengungkung realitas pada wilayah empiris dan bekerja pada kerangka metafisis yang lebih mencakup, dimana tingkat-tingkat realitas lebih tinggi diakui. ${ }^{3}$ Dalam bukunya yang berjudul, The Holy Qur'an and The Science of Nature, (1984) Mehdi Golshani mengibaratkan sains ibarat pohon yang dahannya kering. Agar pohon itu tumbuh subur, harus 'disiram' dengan agama. Alasannya karena sains tidak bebas nilai.

Keyakinan bahwa sains modern bersifat netral, bebas nilai, objektif dan sebagainya ternyata hanya produk kejahilan belaka. Masih terbuka lebar bagi upaya menggugat absolutisme sains modern, dengan mengupayakan sains alternatif yang lebih menjamin peradaban yang sesuai dengan tuntutan kemanusiaan, antara lain oleh kaum muslim. Nilai-nilai Islam menghasilkan sains Islam, walaupun sains Islam tidak berurusan dengan produktivitas sains itu sendiri seperti eksperimentasi dan teoretisasi. Nilai agama tidak cukup diwujudkan dalam etika sains, namun konsep ontologis (objek sains) dan epistemologisnya (metode keilmuan) juga harus melibatkan nilai-nilai Islam. Al-Qur'an memang bukan buku sains, melainkan kitab petunjuk. Rujukan al-Qur'an tentang fenomena alam hanya untuk mendekatkan manusia pada Allah dengan cara merenungkan wujud alam. Dalam perpektif al-Qur'an, memahami alam bukanlah usaha yang bermakna kecuali bertujuan memahami Allah dan mendekatkan diri pada-Nya. Karena itu, kesimpulan ilmiah ilmuwan beragama akan berlainan dengan ilmuwan ateis, walaupun

${ }^{3}$ Ibid., h. 14-16. 
menggunakan pendekatan teori yang sama. Bagi ilmuwan yang percaya kepada Tuhan, studi eksperimental tak bisa memberikan pengetahuan final. Pada akhirnya, manusia juga memiliki keterbatasan. Karena itu penalaran ilmiah harus dibarengi dengan perenungan yang tak terikat dengan pengetahuan indrawi.

Gagasan tentang sains sakral dikembangkan Golshani menjadi "sains Islam" seperti dalam bukunya Issues in Islam and Science (2004) sebagai bantahan yang tegas terhadap sains sebagai bebas dari nilai dan ideologi. Hal ini disebabkan semua teori sains, khususnya teoriteori fundamental, melibatkan praanggapan-praanggapan metafisika yang berakar pada world view para saintis bersangkutan.

Golshani mendefinisikan "sains Islam" sebagai jenis sains yang di dalamnya pengetahuan tentang dunia fisik terkandung dalam pandangan dunia Islam. Pemahaman yang keliru tentang makna sains Islam karena sebagian pihak memahaminya sebagai sains yang melibatkan pembahasan tentang apa yang disebut sebagai mukjizat ilmiah al-Qur'an, atau sains yang membahas tentang cara-cara yang mungkin untuk membuktikan adanya Tuhan, atau kegiatan ilmiah harus dilakukan dengan cara baru yang khas "islami”, atau sains yang mencoba menisbatkan asal-usul sains kepada para sarjana muslim, atau bahwa untuk penelitian fisika-kimia, orang harus merujuk pada al-Qur'an dan Sunnah dan secara eksklusif berpaling pada teori-teori dan eksperimen ilmiah lama. Pemahaman yang reduksionis atau cenderung menyederhanakan permasalahan tersebut menurut Golshani jelas sangat tidak relevan dengan makna sains Islam yang ingin mendasarkan penemuan sains pada sebuah eksperimen yang bergantung pada pengandaian-pengandaian (presuppositions) metafisika baik yang eksplisit maupun implisit. Apa yang dimaksudkan sebagai sains islami adalah sains yang berkerangka world view Islam, dimana ciri-cirinya dapat dilihat pada bagaimana posisi eksistensi pencipta tetap terjaga, tidak membatasi alam semesta hanya pada ranah materi saja (materialis), atau ruang saja (parmenides), atau data indra saja (positivis), atau sebatas angkaangka saja (pythagorean). Di samping itu tujuan tetap dinisbatkan pada alam semesta, serta menerima tertib moral bagi alam semesta.

Dalam pandangan Golshani, sains tidak bisa dipisahkan dari seperangkat nilai yang mengitarinya. Walaupun sains merupakan 
fakta saintifik yang berakar pada realitas obyektif, dan memiliki metode universal yang khas, terdiri dari eksperimen, observasi dan kerja teoretis, kerja saintifik sangat sarat dengan praduga-praduga filosofis dan keagamaan. Sementara metafisika memainkan peran penting pada segenap tahapan aktivitas saintifik, meskipun bisa saja semua itu berlangsung tanpa disadari. Biasanya praduga-praduga metafisika terjadi pada saat aktifitas saintik dilakukan, terutama pada saat penalaran teoritis dan penafsiran data (selain pengumpulan dan penyusunan fakta). Pada titik ini, seorang teistik melihat pada fakta dan mengasimilasikannya dalam konteks teistik, sementara seorang ateis akan menafsirkan fakta dengan mengikuti kecenderungan ateistiknya. ${ }^{4}$

Saat ini paham ateisme tampaknya mendapatkan aksentuasi dan ekspresi yang semakin canggih, terutama dengan munculnya figur-figur ilmuwan ternama seperti Stephen Hawking, Richard Dawkins, Peter Atkins, Michael Ruse, dan Charles Darwin. ${ }^{5}$ Pada kasus seputar teori evolusi Darwin misalnya, dia telah mengubah world view secara radikal lewat dua mantra ajaibnya: "seleksi alam" (natural selections) dan "yang layak yang akan terus hidup" (survival of the fittest, istilah ini dimunculkan lebih dulu oleh Herbert Spencer saat membahas filsafat evolusi tapi populer setelah digunakan oleh Darwin). Darwin dianggap memisahkan Tuhan jauh-jauh dari tindakan penciptaan, meski ada yang berpandangan bahwa "menciptakan sesuatu dengan potensi evolusi bawaan adalah lebih hebat daripada menciptakan suatu entitas yang baku". On the Origin of Species (2002) mendapat kecaman dari banyak kalangan terutama oleh agamawan karena dianggap tidak mendukung gambaran mengenai penciptaan seperti yang tertuang dalam kitab suci.

Mahmoud Ayoub ${ }^{6}$ melihat perdebatan panas tentang ideide Darwin yang meletup pada paruh kedua abad kesembilan belas baik oleh kalangan Islam maupun Kristen tidaklah terlalu

${ }^{4}$ Mehdi Golshani, "Science and The Sacred"....., h. 9.

${ }^{5}$ Keith Ward, God, Chance and Necessity, (Oxford \& England, Oneworld University Press, 1996), h. 34-39.

${ }^{6}$ Mahmoud Ayoub, "Creation or Evolution: Some Muslim Perspective", dalam International Conference on Religion and Science, (Yogyakarta: Comparative Religious Studies Gadjah Mada University and Templeton Foundation, USA, 2003), h. 1-2. 
banyak tentang konsep evolusi sebagai sebuah prinsip filosofis atau ilmiah, tetapi lebih pada pandangan Darwin tentang manusia yang bertabrakan secara langsung dengan pandangan Bibel dan Qur'an yang memandang manusia sebagai mahkota ciptaan dan wakil Tuhan di muka bumi, bukan sebagai keturunan kera besar, dimana manusia dan kera berbagi nenek moyang yang sama. Dalam hal ini Ayoub mungkin ingin menjelaskan adanya kutub "abu-abu" dalam peta pertentangan antara agama dan sains. Yang dimaksud dengan kutub abu-abu di sini adalah para ilmuwan yang percaya pada fakta evolusi a la Darwin, sekaligus percaya pada Tuhan (Supernatural, Beyond Natural, atau Kekuatan Super). Tokoh-tokoh yang masuk dalam wilayah ini seperti Arthur Peacocke, Michael Ruse, John Polkinghorne, dan Robert John Russel. Pada intinya pesan yang ingin mereka sampaikan adalah bahwa apa yang tampak sebagai konflik antara agama dan sains kerapkali adalah konflik antar teologi. Sebut saja misalnya perlawanan para agamawan terhadap teori evolusi baik dari kalangan Islam maupun Kristen.

Kelompok kreasionisme baru atau Intelligent Design seperti Harun Yahya (Adnan Oktar) dari Turki, dengan serta merta menyamaratakan evolusi sama dengan Darwinisme, sama dengan materialisme, ateisme, dan segala sesuatu yang salah di dunia ini. Padahal evolusi jelas tidak sama dengan Darwinisme. Evolusi adalah sejarah alam di planet bumi ini. Gerakan iri terhadap sains ini juga ditunjukkan oleh para fundamentalis Protestan yang turut memberikan bantuan pendaan kepada Harun Yahya dalam melakukan penelitiannya. ${ }^{7}$ Berbeda dengan para kreasionis awal yang menjadikan kitab suci sebagai landasan argumen, mereka adalah para penolak total argumen tentang evolusi berdasarkan data-data empiris yang melemahkan teori evolusi, walaupun secara umum argumen mereka masih sangat mirip dengan kreasionisme Selain itu masih kuatnya teologi lama yang mengangkat wacana tentang God of the gaps, dimana Tuhan ditemukan dalam gap atau kotak-kotak hitam dalam teori ilmiah. Paham ini menyatakan bahwa

TWilliam Grassie, "Evolution and Religion: Towards a Constructive Theology of Nature", dalam International Conference on Religion and Science, (Yogyakarta: Comparative Religious Studies Gadjah Mada University and Templeton Foundation, USA, 2003), h. 6-7. 
ketika penjelasan atau teori ilmiah telah berada pada ambang batas atau jalan buntu, maka Tuhan dihadirkan sebagai satu-satunya penjelasan. (lihat kasus Newton dan William Paley, dimana Tuhan sebagai desainer kompleksitas).

Model Tuhan yang digunakan guna menutupi celah-celah dalam teori-teori ilmiah misalnya Tuhan Deisme, dimana Tuhan sebagai pencipta semesta membiarkan kreasinya bergerak sendiri mengikuti hukum alam yang dibuat-Nya, sementara Dirinya "beristirahat" sambil menonton hasil ciptaannya. Seperti Pecipta Jam (Boyle; God as A Clock Maker), Tuhan mungkin sesekali mereparasi buatannya kalau memang ada yang perlu diperbaiki.

Celakanya, jika gaps tersebut menyusut, dengan kata lain sains semakin mampu menjelaskan rahasia alam semesta, maka ruang bagi Tuhan pasti akan makin berkurang. Akhirnya agama seperti dikatakan Zainal Abidin Bagir bak membuat kuburannya sendiri. ${ }^{8}$ Di sini dibutuhkan pengupayaan bagi rekonstruksi teologi lama menuju teologi yang lebih dinamis seperti panenteisme atau teologi proses yang diperkaya oleh gambaran dunia baru berdasarkan teoriteori baru sains. Syaratnya adalah sikap yang cukup liberal dalam berhadapan dengan teks dan tradisi, walaupun hal ini dikhawatirkan menjadikan teologi sebagai bulan-bulanan sains jika terus menerus direvisi. Tapi Huston Smith, ${ }^{9}$ justru meragukan akan terciptanya teologi baru yang sensitif terhadap temuan sains, bahkan bisa jadi yang muncul adalah upaya-upaya para ilmuwan teolog tersebut justru melahirkan "kolonisasi teologi oleh sains."

Namun demikian modernitas tidak bisa serta merta diadili dan dicap sebagai sebagai pemberangus agama. Menurut Max Weber, ${ }^{10}$ rasionalisasi (sarana, prilaku, keyakinan) sebagai kunci memahami modernitas dapat menggiring agama masuk ke sebuah wilayah baru, suatu pemaknaan agama yang lebih bervariasi dan terbuka. Dengan demikian secara filosofis dan sosiologis, agama dan

8Zainal Abidin Bagir, "Pluralisme Pemaknaan dalam Sains dan Agama: Beberapa Catatan Perkembangan Mutakhir Wacana “Sains dan Agama”, dalam Relief, Journal of Religious Issues, Volume 1, no. 1, 2003, h. 13-17.

${ }^{9}$ Huston Smith, Why Religion Matters, The Fate of the Human Spirit in an Age of Disbelief, (Harper San Fransisco: HarperCollins Publisher, 2001), h. 72-75.

${ }^{10} \mathrm{M}$. Poole, "A Response to Richard Dawkins", dalam Science and Christian Belief, 6. 1994, h. 87. 
sains dimungkinkan dapat dapat terjembatani dengan baik. Melalui modernitas, sains dan agama juga dapat tergarap dengan baik melalui apa yang disebut Habermas sebagai wilayah pribadi maupun publik. Secara politik, jika agama mampu mengembangkan masyarakat yang berkeadilan dan berkemakmuran, maka pada dasarnya hal tersebut berkesesuaian dengan maksud dan arah modernitas, dan begitupun sebaliknya.

\section{Menjembatani Sains dan Agama}

Ketika agama dan sains mengalami ketegangan, dibutuhkan berbagaicara untukmenjembatanikeduanyaagardapatsalingmengisi dan tidak saling meniadakan. Agama seringkali dibenturkan dengan modernitas sebagai ibu yang melahirkan sains dan teknologi.

John F. Haught, seorang guru besar teologi dari Universitas Georgetown, Amerika Serikat, mengandaikan adanya spektrum yang cukup luas dalam pandangan tentang hubungan agama dan sains; dari ekstrim konflik, sampai peleburan total. Beberapa pertanyaan yang berhubungan dengan relasi antara sains dan agama seperti dibahas dalam bukunya yang berjudul, Science and Religion: From Conflict to Conversation (1995) seperti; apakah agama bertentangan dengan sains?; apakah sains menyingkirkan Tuhan yang personal?; apakah evolusi menyingkirkan keberadaan Tuhan?; dapatkah hidup direduksi ke dalam ilmu kimia?; apakah alam semesta ini diciptakan?; apakah kita benar-benar produk alam semesta ini?; mengapa ada kompleksitas dalam alam?; apakah alam semesta mempunyai tujuan?; dan apakah agama bertanggung jawab atas krisis ekologi?

Beberapa pendekatan pemikiran yang ditawarkan Haught tampaknya cukup menarik untuk dikembangkan dalam hubungannya memahami posisi hubungan sains dan agama, seperti; pendekatan konflik, yang memandang agama dan sains secara intrinsik berlawanan; pendekatan kontras, yang memberikan ruang bagi kedua wilayah untuk saling menghargai integritas masing-masing; pendekatan kontak, yang menyarankan agama dan sains untuk saling bertukar pandang guna memperkaya perspektif tentang kenyataan; dan pendekatan konfirmasi, sebagai kesatuan fundamental sains dan agama yang menyarankan mereka agar dapat saling mengukuhkan karena sama-sama bermaksud mencari kebenaran yang ada pada 
inti terdalam eksistensi. Menurut Haught, "justru karena mereka berasal dari asal-usul yang sama, yaitu dari kepedulian fundamental akan kebenaran, maka kita tidak akan pernah membiarkan mereka menelusuri jalan-jalan mereka sendiri terpisah satu sama lain."

Lebih jauh Fritjof Capra meyakinkan para agamawan dan ilmuwan bahwa paralelisme antara sains keras (fisika modern) dengan spiritualitas (mistisisme) sangat dimungkinkan. Ahli fisika partikel ini menawarkan gagasan perihal kesejajaran antara fisika modern dan mistisisme Timur. Ia mencontohkan kesejajaran konsep dualisme gelombang/partikel dan yin/yang dalam faham Tao. Bagi Capra, fisika modern dan mistisisme merupakan pasangan manifestasi pikiran manusia yang saling melengkapi; yang satu dari fakultas rasional dan yang lain dari fakultas intuitif. Mistik, menurut Capra, penting untuk memahami sesuatu, sementara fisika modern penting bagi kehidupan modern. ${ }^{11}$

\section{E. Penutup}

Satu hal yang patut diapresiasi adalah bahwa saat ini para agamawan (ilmuwan teolog) terutama dari kalangan Islam maupun Kristen telah memiliki kecenderungan positif untuk terjun langsung dalam dunia sains yang sangat luas ini. Kalau selama ini kalangan agamawan banyak yang hanya berada di pinggiran sebagai penonton yang sering kecewa atau dikecewakan oleh arus perkembangan sains, maka "agama" paling tidak telah memiliki wakil-wakil tangguhnya, masuk kegelanggang dan bermain dengan aturan sains. Tokoh-tokoh seperti Ian Barbour, Keith Ward, Peacocke, Mehdi Golshani, Huston Smith, Fritjof Capra, dan tokoh-tokoh lainnya merupakan sebagian dari pelaku wacana baru dalam menghubungkan sains dan agama.

Yang jelas, ditengah dinamika yang terjadi antara para ilmuwan teistik dengan ilmuwan ateistik, tampaknya selalu ada ruang bagi Tuhan dalam sains. Misalnya teori tentang mutasi DNA dan teori tentang Dentuman Besar yang menghadirkan kekuatan Pemandu dan Perekayasa bagi suatu kerja alam. Sebagai contoh dalam proses mutasi DNA, bahwa mutasi tidak akan pernah bisa terjadi bahkan dalam waktu ratusan juta tahun jika dilakukan secara acak, sehingga suatu

${ }^{11}$ Lebih lanjut baca Fritjof Capra, The Tao of Physics: An Exploration of the Parallels Between Modern Physics and Eastern Mysticism. (New York: Bantam Books. 1977). 
mutasi mutlak membutuhkan Pemandu bagi proses mutasi sehingga bisa berjalan dengan baik. Selain itu dalam teori Dentuman Besar, dapat dipastikan bahwa dalam proses penyusunan dan penyusutan jagad raya tidak mungkin hanya merupakan suatu uji coba semata karena pecahan-pecahan elektron yang terbentuk setelah peristiwa Dentuman Besar memiliki massa diam (9,110 kali 10 pangkat minus $31 \mathrm{~kg}$ ) yang tepat dalam mendukung suatu pembentukan jagad raya yang sempurna. Begitu juga pertentangan yang terjadi antara teori evolusi dan agama seharusnya tidak perlu dikonfrontasikan karena keduanya dapat saling mengisi dan mendukung. Disini pentingnya upaya melakukan integrasi antara akal yang melahirkan sains dengan pandangan teologis yang lebih terbuka dalam memandang dalil-dalil kitab suci yang berbicara tentang fenomena alam.

Dengan pemahaman yang holistik tentang cara alam dan cara Tuhan bekerja, maka kehadiran agama atau Tuhan dalam sains seharusnya tidak perlu diingkari, apalagi ditakuti. Apa yang dikatakan Keith Ward dalam bukunya God, Chance and Necessity, bahwa "God is beginning to argue back", merupakan tanda bahwa hubungan antara agama dan sains sesungguhnya dapat didekatkan dengan cara-cara yang lebih konstruktif dan seimbang jika keduanya masih sepakat untuk menemukan hakikat eksistensi dan problem jagad raya dalam sebuah tanggung jawab yang sama. Tanpa mengabaikan persoalan internal yang dihadapi baik oleh sains maupun agama, keduanya masih memiliki tanggung jawab kolektif yang patut dicarikan penyelesaiannya secara bijak dan akurat. Persoalan yang dihadapi seperti bencana yang terjadi pada masa kini dan mendatang: kemiskinan penduduk, perubahan iklim, erosi dan kekeringan, penebangan hutan, limbah, ketimpangan kekayaan, kriminalitas, degradasi moral, dan masalah-masalah lainnya menuntut jawaban dan solusi yang tepat dalam rangka mengejawantahkan peran sains dan agama sebagai pro kelestarian alam dan kemanusiaan. Bumi dan seisinya masih membutuhkan tangan-tangan sains dan agama guna memberikan rasa aman bagi semesta sehingga kesinambungan dan keselarasan dapat terjalin dan tertata, sampai semua akhirnya menyadari bahwa alam semesta dan seisinya adalah Hadiah Terindah dari Sang Pencipta. 


\section{Daftar Pustaka}

Ayoub, Mahmoud, "Creation or Evolution: Some Muslim Perspective", makalah International Conference on Religion and Science, Yogyakarta: Comparative Religious Studies Gadjah Mada University and Templeton Foundation, USA. 2003.

Barbour, Ian G., When Science Meets Religion: Enemies, Strangers or Partners, San Fransisco: Harper, 2000.

Capra, Fritjof, The Tao of Physics: An Exploration of the Parallels Between Modern Physics and Eastern Mysticism. New York: Bantam Books. 1977.

Darwin, Charles, The Origin of Species (Asal usul Spesies), Jakarta: Ikon Teralitera. 2002.

Golshani, Mehdi, "Science and The Sacred:Sacred Science vs. Secular Science". Makalah International Conference on Religion and Science, Yogyakarta: Comparative Religious Studies Gadjah Mada University and Templeton Foundation, USA. 2003.

, Issues in Islam and Science. Teheran Iran: IHCS. 2003.

, The Holy Quran and The Science of Nature.IGCS:Binghamton University. 1997.

Grassie, William, "Evolution and Religion: Towards a Constructive Theology of Nature", makalah International Conference on Religion and Science, Yogyakarta: Comparative Religious Studies Gadjah Mada University and Templeton Foundation, USA. 2003.

Guiderdoni, Bruno, “Did The Universe Begin?: Cosmology and Metaphysics for the XXIst Century", makalah International Conference on Religion and Science, Yogyakarta: Comparative Religious Studies Gadjah Mada University and Templeton Foundation, USA. 2003.

Haught, John. F. Science and Religion: From Conflict to Conversation, New York: Paulist Press. 1995.

Poole, M., "A Response to Richard Dawkins", dalam Science and Christian Belief, 6. 1994. 
Relief, Journal of Religious Issues, Volume 1, no. 1, Yogyakarta, 2003.

Smith, Huston, Why Religion Matters: The Fate of the Human Spirit in an Age of Disbelief, Harper San Fransisco: HarperCollins Publisher, 2001.

Ward, God Keith, Chance and Necessity, Oxford, England: Oneworld University Press. 1996. 
Samsul Hidayat

halaman ini bukan sengaja dikosongkan 